\title{
Adrenal Gland Myelolipoma
}

National Cancer Institute

\section{Source}

National Cancer Institute. Adrenal Gland Myelolipoma. NCI Thesaurus. Code C3736.

A benign soft tissue lesion arising from the adrenal gland. It is composed of mature adipose and hematopoietic/lymphoid tissues. 